\title{
EDUKASI PADA MASYARAKAT DESA MEKARBAKTI KECAMATAN PAMULIHAN \\ KABUPATEN SUMEDANG TENTANG PENTINGNYA UPAYA-UPAYA PENCEGAHAN PENULARAN PENYAKIT COVID-19
}

\author{
Iwan Shalahuddin ${ }^{1}$, Udin Rosidin ${ }^{2}$, Dadang Purnama ${ }^{3}$ \\ ${ }^{1}$ Fakultas Keperawatan Universitas Padjadjaran Kampus Garut \\ ${ }^{2}$ Fakultas Keperawatan Universitas Padjadjaran Kampus Garut \\ ${ }^{3}$ Fakultas Keperawatan Universitas Padjadjaran Kampus Garut \\ Email: shalahuddin@unpad.ac.id, udin.rosidin@unpad.ac.id, \\ dadang.purnama2017@unpad.ac.id
}

\begin{abstract}
ABSTRAK
Desa Mekarbakti tidak memiliki program atau aturan khusus terkait pencegahan penularan Covid 19. Pelayanan screening tes Covid 19 (Rapid test dan Swab test) juga belum mencakup keseluruhan masyarakat di Desa Mekarbakti, hanya beberapa orang yang memiliki tanda gejala, memiliki kontak erat dengan orang positif Covid 19, dan yang memiliki riwayat perjalanan dari daerah zona merah Covid 19 yang diprioritaskan mendapatkan screening tes Covid 19 (Rapid test dan Swab test. Tujuan pengabdian untuk menjelaskan cara pencegahan penularan penyakit Covid 19 yang baik dan benar, menjelaskan dampak yang ditimbulkan jika tidak melakukan upaya tersebut, menjelaskan solusi untuk masyarakat yang belum menerapkan upaya pencegahan. Metode yang digunakan dimasa pandemi ini, kegiatan promosi kesehatan dilakukan dengan pemberian pendidikan kesehatan melalui virtual menggunakan platform Whatsapp Group Chat dengan metode ceramah, Tanya jawab, diskusi dan demonstrasi.. Hasil Jumlah audience : 46 orang Audience yang dihadiri oleh sejumlah stakeholder Desa Mekarbakti seperti petugas promosi kesehatan dari puskesmas haurngombong, bidan desa, kader dan masyarakat desa mekarbakti, sebelum dilakukan kegiatan peserta sudah mengenal tentang upaya penegahan Covid 19 hanya belum tahu cara yang benar, setelah di lakukan edukasii peserta secara keseluruhan dapat memahami dengan benar. peserta tampak antusian mengikuti kegiatan. Kesimpulan Peserta mengikuti penyuluhan dengan senang hati karena penyuluhan dilaksanakan dengan menyenangkan melalui virtual dan di tempat tinggal masing-masing. Kegiatan penyuluhan berjalan kondusif karena peserta memperhatikan materi yang disampaikan dengan baik.
\end{abstract}

Kata Kunci: Covid-19, Edukasi, Masyarakat, Perilaku

\begin{abstract}
Mekarbakti Village does not have any special programs or regulations related to the prevention of Covid 19 transmission. Covid 19 test screening services (Rapid test and Swab test) also do not cover the entire community in Mekarbakti Village, only a few people who have symptomatic signs, have close contact with positive Covid people 19, and those who have a travel history from the Covid 19 red zone that are prioritized for getting the Covid 19 test screening (Rapid test and Swab test. The purpose of dedication is to explain how to prevent the transmission of the Covid 19 disease that is good and correct, explaining the impact if not making efforts The method used in this pandemic, health
\end{abstract}


promotion activities are carried out by providing virtual health education using the Whatsapp Group Chat platform with the method of lectures, questions and answers, discussions and demonstrations. Audience 46 people which was attended by a number of Mekarbakti Village stakeholders such as health promotion officers from the Haurngombong Community Health Center, village midwives, cadres and the community of Bembangbakti village, before the activity was carried out the participants already knew about the efforts to prevent Covid 19 but did not know the right way, after educating the participants as a whole they could understand correctly. the participants seemed enthusiastic about participating in the activity. Conclusion Participants take part in the counseling happily because the counseling is carried out fun through virtual and in their respective residences. Extension activities run conducive because the participants pay attention to the material presented well.

Keywords: Covid-19, Education, Community, Behavior

\section{PENDAHULUAN}

Pembangunan kesehatan untuk mencapai Indonesia Sehat 2015 bertujuan untuk meningkatkan kesadaran, kemauan dan kemampuan hidup sehat bagi setiap orang agar terwujud derajat kesehatan yang setinggi-tingginya dan perubahan paradigma sehat yaitu upaya untuk meningkatkan kesehatan bangsa Indonesia agar mampu mendorong masyarakat untuk bersikap mandiri dalam menjaga kesehatan sendiri melalui kesadaran yang tinggi yang mengutamakan upaya promotif dan preventif (Depkes, 2014).

Guna mewujudkan derajat kesehatan masyarakat yang optimal tersebut berbagai upaya kesehatan telah diselenggarakan. Salah satunya adalah upaya perawatan kesehatan masyarakat yang lebih dikenal dengan upaya keperawatan komunitas. Keperawatan komunitas merupakan bentuk pelayanan atau asuhan langsung yang berfokus kepada kebutuhan dasar komunitas, yang berkaitan dengan kebiasaan atau pola perilaku masyarakat yang tidak sehat, ketidakmampuan masyarakat untuk beradaptasi dengan lingkungan (bio, psiko, sosial, kultural, maupun spiritual). Intervensi keperawatan komunitas yang dilakukan difokuskan pada tiga level preventif atau pencegahan yaitu preventif primer yang pelaksanaan difokuskan pada pendidikan kesehatan konseling, preventif sekunder dan preventif tersier (Effendi \& Makhfudli, 2015).

Tujuan keperawatan komunitas merupakan upaya untuk pencegahan dan peningkatan kesehatan masyarakat melalui upaya-upaya sebagai berikut: Pelayanan keperawatan secara langsung (direct care) terhadap individu, keluarga, kelompok dalam konteks komunitas. Perhatian langsung terhadap kesehatan seluruh masyarakat (health general community) dengan mempertimbangkan permasalahan kesehatan masyarakat yang dapat mempengaruhi keluarga, individu, dan kelompok. Kegiatan pelayanan keperawatan berfokus untuk meningkatkan pengetahuan dan keterampilan keperawatan serta membimbing untuk menanamkan kebiasaan dan perilaku hidup sehat sehingga mampu meningkatkan derajat kesehatan (Mubarak, 2017: Fitriani, N. I, 2020). 
Desa Mekarbakti merupakan desa hasil pemekaran dari Desa Haurngombong pada tahun 1983, Saat itu, desa Mekarbakti merupakan desa yang sangat luas sehingga pelayanan publik yang dilakukan tidak dapat dilakukan secara optimal akibat dari luasnya wilayah dan banyaknya penduduk. Sehingga masyarakat terutama yang jauh mengusulkan dilakukannya pemekaran terhadap desa Haurngombong. Pada tahun 1982, pemerintah kabupaten sumedang menyetujui dilakukannya pemekaran, hasil pemekaran itu terbagi menjadi tiga desa yaitu Mekarbakti, Cilembu, dan Haurngombong itu sendiri. Batas Wilayah Desa Mekarbakti yaitu: bagian Utara adalah jalan PUK Cilembu, bagian timur adalah gunung kareumbi, bagian selatan adalah Desa Sindanggalih Kecamatan Cimanggung, bagian barat adalah Jalan SimpangParakamuncang.

Berdasarkan hasil wawancara dari kepala desa, Saat awal mula adanya Covid19, di desa Mekarbakti menerapkan sistem PSBB seperti yang dianjurkan pemerintah dan saat era new normal ini sistem PSBB dihentikan, namun di Desa upaya yang dilakukan desa dalam pencegahan dan penularan Covid-19 di desa adalah diadakannya penyemprotan seperti di masjid, warga serta karang taruna antusias membantu bila ada kegiatan penyemprotan. Masyarakat memiliki keyakinan bahwa wabah Covid-19 ini segera berakhir.

Pada saat pandemi COVID-19 pihak desa melakukan upaya pencegahan COVID-19 membuat tim satgas COVID-19 yang terdiri atas remaja karang taruna desa. Desa Mekarbakti juga menjalin kerja sama dengan fasilitas pelayanan kesehatan terdekat dari desa juga menjalin kerja sama dengan pihak luar seperti perusahaan-perusahaan swasta di sekitar dalam penanganan pencegahan COVID-19. Dalam kerja sama tersebut, Desa Mekarbakti mendapatkan beberapa bantuan seperti tempat cuci tangan, paket sembako, pendirian posko siaga COVID-19 dan kebutuhan penunjang lainnya seperti bensin dan rokok untuk para petugas yang berjaga di posko.

Desa Mekarbakti tidak memiliki program atau aturan khusus terkait pencegahan penularan Covid 19. Pelayanan screening tes Covid 19 (Rapid test dan Swab test) juga belum mencakup keseluruhan masyarakat di Desa Mekarbakti, hanya beberapa orang yang memiliki tanda gejala, memiliki kontak erat dengan orang positif Covid 19, dan yang memiliki riwayat perjalanan dari daerah zona merah Covid 19 yang diprioritaskan mendapatkan screening tes Covid 19 (Rapid test dan Swab test). Pada saat ini tidak ditemukan warga Desa Mekarbakti yang memiliki tanda gejala terduga Covid 19. Apabila ditemukan masyarakat yang memiliki tanda gejala Covid 19, maka akan diberikan anjuran untuk melakukan isolasi mandiri selama 14 hari dan akan dipantau kesehatannya oleh petugas kesehatan yang memiliki kewenangan tersebut.

\section{MASALAH}

Dalam pelayanan keperawatan komunitas dilakukan pemberian asuhan keperawatan komunitas yang dinilai untuk memberi pengalaman yang nyata dalam mengelola individu, keluarga, kelompok dan masyarakat. Pelaksanaan asuhan keperawata komunitas di Desa Mekarbakti Kecamatan Pamulihan terdiri dari kegiatan pembinaan desa yang nantinya akan dikaitkan dengan isu saat ini yaitu Pandemi Covid-19. Dengan adanya wabah tersebut 
diharapkan masyarakat dapat memiliki kesadaran penuh dalam meningkatkan kesehatan dengan menerapkan perilaku hidup bersih dalam upaya pencegahan penularan Covid-19.

Berdasarkan data dari aplikasi survei mawas diri (AMARI) bahwa Desa Mekarbakti terdapat 2 orang yang pernah kontak erat dengan pasien Covid19 dan berdasarkan dari data aplikasi AMARI tersebut Desa Mekarbakti merupakan desa yang cukup banyak merespon pengisian kuesioner aplikasi AMARI yaitu sebanyak 119 orang dimulai dari Maret sampai dengan 11 September 2020.

Berdasarkan keadaan tersebut, maka akan melakukan survei mawas diri lebih lanjut untuk mengetahui masalah secara spesifik. Data yang telah terkumpul dilakukan identifikasi dan validasi bersama kepala desa, tokoh masyarakat dan masyarakat melalui kegiatan MMD (Musyawarah Masyarakat Desa).

Desa Mekarbakti merupakan sebuah desa yang berada di wilayah Kecamatan Pamulihan, kabupaten Sumedang. Desa Mekarbakti terletak di $\pm 6 \mathrm{~km}$ dari kantor Kecamatan Pamulihan dan $\pm 18 \mathrm{~km}$ dari pusat pemerintahan Kabupaten Sumedang. Desa Mekarbakti terdiri dari 4 dusun dan 9 RW. 9 RW berada di pemukiman penduduk dan $1 \mathrm{RW}$ berada di daerah perumahan baru yang belum ada RT. Jumlah RT keseluruhan dari Desa Mekarbakti adalah 40 RT

Desa Mekarbakti saat pelaksanaan MMD menyatkan bahwa di Desa Mekarbakti Proses sosialisasi sudah berjalan, namun dari masyarakatnya sudah merasa bosan dengan sosialisasi seperti Covid-19 yang itu-itu terus. Himbauan yang sudah diberikan ternyata respon dari masyarakat sudah berkurang masyarakat sudah bosan mendengar himbauan tentang melaksanakan protokol kesehatan. Puskesmas dari program Penkes pun menyatakan bahwa sudah lamanya Covid-19 ini berada ditambahn kebijakan pemerintah yang berubah-ubah membuat masyarakat menjadi jenuh.

Berdasarkan latar belakang di atas, untuk meminimalisasi terjadinya dan dampaknya, perlu diberikan arahan dan pendidikan ilmu pengetahuan yang berkelanjutan, salah satunya dengan memberikan edukasi kesehatan tentang Covid-19 salah satu materinya tentang mengenai 4M (mencuci tangan, memakai masker, menjaga jarak dan menjauhi kerumuna), sehingga secara tidak langsung tingkat kesehatan masyarakat akan terhindar dari penularan Covid-19. 


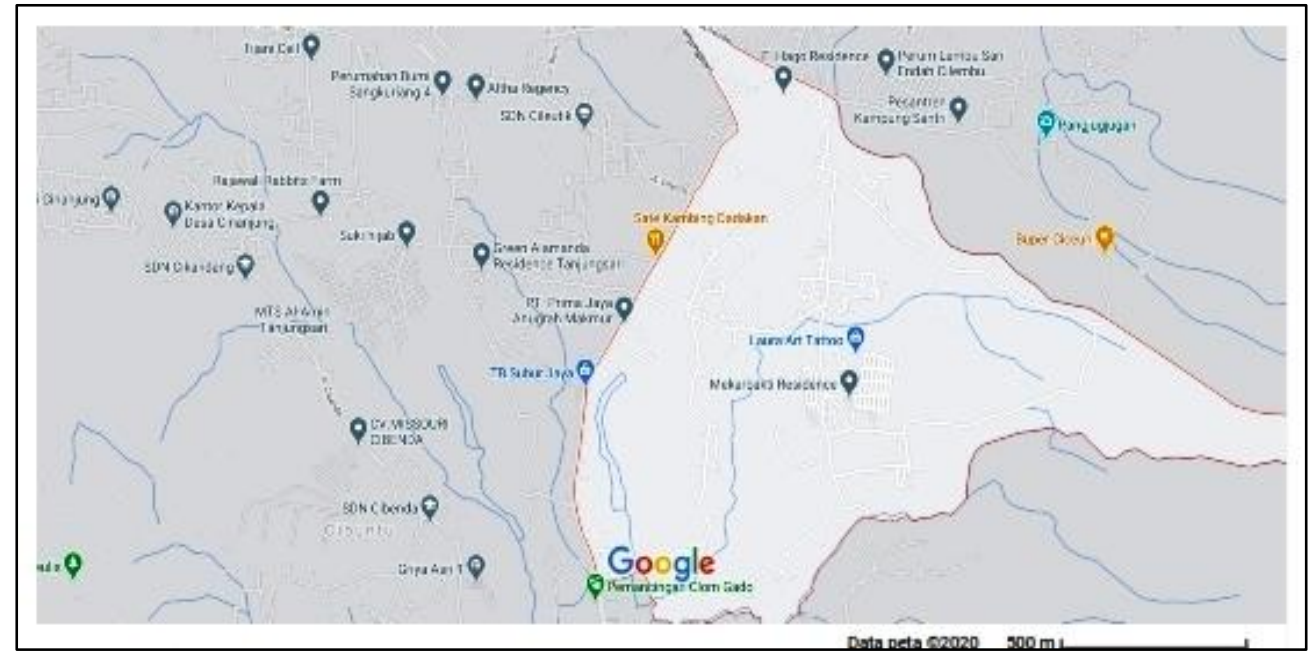

Gambar 2.1. Peta Lokasi Desa Mekarbakti Kecamatan Pamulihan Sumedang

\section{METODE}

Subjek dalam pengabdian ini sasarannya adalah warga masyarakat Desa Mekarbakti Kecamatan Pamulihan Kabupaten Sumedang yang beresiko terhadap penyebaran dan penularan covid-19. Tahap persiapan melakukan koordinasi dengan Puskesmas Haurgombong dan Desa Mekarbakti untuk permohonan izin kegiatan, identifikasi mengenai keadaan umum, pengetahuan, perilaku serta upaya penanggulangan covid-19 dan Mempersiapkan sumber daya yang dibutuhkan yang melibatkan mahasiswa Fakultas Keperawatan yang sedang melaksanakan Kegiatan profesi keperawatan Komunitas di daerah tersebut.

Tahap implementasi dengan merencanakan strategi komunikasi lalu kemudian dipilihlah penyuluhan edukasi dan motivasi sebagai langkah strategi yang diambil, dilakukan survei pengetahuan dan perilaku kepada warga Desa Mekarbakti, menyusun media informasi melalui gambargambar yang disajikan dalam penyuluhan, leaflet dan poster serta video mengenai pentingnya upaya melakukan Pencegahan Covid-19. Metode yang dilakukan dalam pendidikan kesehatan adalah penjelasan atau ceramah yang diberikan oleh pemateri kepada semua masyarakat Desa Mekarbakti secara virtual, dan diikiuti dengan tanya jawab, pemateri harus memastikan semua masyarakat Desa Mekarbakti mengerti materi yang telah disampaikan dengan memastikan kembali kepada peserta apabila ada hal-hal yang kurang jelas. Melakukan Pre Test tentang Penyakit Covid-19 melalui pertanyaan secara lisan dan Melaksanakan penyuluhan kesehatan pentinggnya upaya melakukan pencegahan covid-19, upaya upaya perilaku dalam mengatasi dan mengobati covid-19 serta upaya-upaya yang terintegrasi dalam penanggulangan resiko terjadinya penularan covid-19. Media informasi bagi warga ini disusun oleh tim pengabdian pada masyarakat yang bekerjasama dengan mahasiswa serta melakukan Post Test tentang Covid-19 melalui pertanyaan secara lisan.

Metode yang digunakan antara lain Ceramah/ Lecture untuk mempermudah peserta untuk memahami isi dari materi yang akan disampaikan oleh mahasiswa sebagai Ilmu pengetahuan; Metode Tanya jawab yang merupakan usaha penyingkiran rintangan selama atau sesudah berlangsungnya masa 
ceramah. Hal ini untuk mempermudah para peserta menanyakan soal tentang materi yang diberikan; Metode Diskusi agar para peserta mampu memecahkan masalah yng dihadapi dari pertanyaan-pertanyaan yang diberikan dengan topik pembahasan materi. Metode diskusi juga bertujuan untuk tukar menukar gagasan, pemikiran, informasi/pengalaman diantara peserta, sehingga dicapai kesepakatan pokok-pokok pikiran (gagasan ,kesimpulan); Metode demonstrasi dengan harapan para peserta dengan memutarkan video "Langkah Cuci tangan ", Pemakaian masker dan pembatasan kerumunan, selanjutnya akan diperagakan oleh mahasiswa,kemudian diikuti oleh para peserta. Sehingga, setelah video diputar dan peragaan sudah dicontohkan oleh mahasiswa, diharapkan peserta dapat memahami, mengingat, sekaligus mendapatkan gambaran bagaimana cara mencegah penyebaran Covid-19 dengan benar. Dengan mendemonstrasikan, maka akam menstimulasi semua panca indera para peserta.

\section{HASIL DAN PEMBAHASAN}

Berdasarkan hasil rekapitulasi hasil pengkajian kebutuhan belajar dapat terlihat bahwa ada sebagian peserta, kebutuhan belajar yang termasuk kedalam kebutuhan belajar : Perceived needs Karena ada sebagian mengetahui dampak dari tidak melakukan upaya pencegahan penularan Covid-19 bagi masyarakat; Unperceived needs Karena ada sebagian peserta yang belum mengetahui dampak dari tidak melakukan upaya pencegahan yang berbahaya bagi kesehatan; Misperceived needs Karena ada sebagian peserta yang mengetahui bahaya jika melakukan upaya pencegahan penularan Covid-19, tetapi masih ada kebiasaan yang tidak mengetahui cara melakukan upaya-upaya pencegahan penularan Covid-19 seperti cara mencuci tangan menggunakan sabun, cara memakai masker yang benar dan cara membatasi diri terhadap kerumunan. Data Rekapitulasi Hasil Pengkajian Kebutuhan Belajar Jumlah audience : 46 orang, Audience terdiri dari para tokoh masayarakat, ketua RW, Ketua RT, Karang Taruna, Kader Kesehatan dan tokoh agama lainya yang berada di Desa Mekarbakti.

Kegiatan pendidikan kesehatan yang dilaksanakan pada hari Sabtu, 03 September 2020 pukul 16.00 - selesai WIB, dilakukan secara virtual melalui aplikasi whatsapp group. Kegiatan ini dimulai dengan pembukaan oleh MC, lalu sambutan oleh dosen, Kepala Desa Mekarbakti dan perwakilan mahasiswa. Kegiatan diawali dengan MC menanyakan sejauh mana peserta mengetahui tentang cara-cara pencegahan penularan Covid-19, apakah peserta pernah mengalaminya, dan dampak apa saja yang akan muncul apabila tidak melakukan upaya pencegahan. Dari semua jawaban peserta, peserta cukup mengenal dengan bahaya tidak dari tidak melakukan upaya pencegahan penularan Covid-19, namun peserta masih belum paham mengenai dampak apa saja yang akan timbul pada peserta yang mengalami kebiasaan tidak melakukan upaya pencegahan Covid-19. Kemudian peserta diberi pre test secara lisan untuk mengetahui sejauh mana pengetahuan nya sebelum materi disampaikan oleh pemateri.

Kegiatan dilanjutkan dengan pemberian materi menggunakan PPT dan penampilan video yang sudah disiapkan, agar peserta tetap tertarik untuk mengikuti acara dan tidak bosan. Materi yang disampaikan ialah mengenai 
pengertian penyakit, tanda dan gejala, faktor resiko dan cara pencegahan dari penyakit coronavirus (COVID-19) (Alia, E. C, 2020).

Pemberian materi diawali dengan materi ini, pemateri langsung menampilkan PPT yang sudah disiapkan. Saat sesi pematerian berjalan dengan lancar dan peserta tampak fokus dan memerhatikan apa yang sedang dipresentasikan. Setelah pemberian materi, dilanjutkan metode yang digunakan ialah ceramah, hal tersebut bermaksud sharing kepada peserta agar tidak terlalu terlihat menggurui maka pemateri pun sambil berinteraksi dengan peserta.

Setelah materi selesai disampaikan, dilanjut dengan penayangan video cara pencegahan penularan Covid-19 yang benar dan selanjutnya sesi tanya jawab yang bertujuan untuk mengetahui sejauh mana perubahan peserta dari yang sebelumnya dan sesudahnya diberikan penkes. Pertanyaan dibacakan oleh pemateri dan peserta antusias untuk menjawab pertanyaan, total ada 5 pertanyaan yang dijawab semua dengan benar oleh beberapa orang peserta.

Evaluasi penyuluhan mengenai bahaya penyakit Covid-19 dilaksanakan secara virtual dengan jumlah peserta kurang lebih 46 peserta. Peserta penyuluhan terlihat antusias saat pemberian materi berlangsung. Peserta mengikuti penyuluhan dengan senang hati karena penyuluhan dilaksanakan dengan menyenangkan. Kegiatan penyuluhan berjalan kondusif karena peserta memperhatikan materi yang disampaikan dengan baik. Hal ini dibuktikan dengan banyaknya peserta yang tertarik untuk menjawab pertanyaan ketika sesi tanya jawa.

Efektifnya fungsi media ajar yang digunakan dapat terlihat jelas oleh seluruh peserta. Karena penyuluhan dilakukan secara virtual sehingga para peserta khususnya warga masyarakat Desa Mekarbakti tidak perlu harus berbondong bondong hadir ke suatu tempat, teteapi cukup hanya dengan menyimak dari virtual di tempat tinggalnya masing-masing. Hal ini dapat menjadikan keefektifan penjelasan materi. Respon peserta yang baik terlihat dengan antusias untuk mengikutinya dari awal hingga akhir kegiatan.

Kegiatan ini dilaksanakan melalui penyuluhan online, yaitu dengan kuliah lewat whatsapp (KULWAP) dalam grup. Kuliah ini dilakukan sesuai dengan rencana yang telah disusun. Upaya yang dilakukan merupakan bagian dari upaya pencegahan (preventif) dan pendidikan kesehatan (promotif) yang juga merupakan tugas masyarakat desa dalam memutus mata rantai penyebaran dan penularan Covid-19. Promosi kesehatan ini mengacu pada Covid-19 yang berfokus pada pencegahan penularan Covid-19 sesuai dengan anjuran pemerintah meliputi protokol kesehatan yaitu mengenai $4 \mathrm{M}$ (mencui tangan, memakai masker, menjaga jarak minimal 1 meter, dan menjauhi kerumunan). 

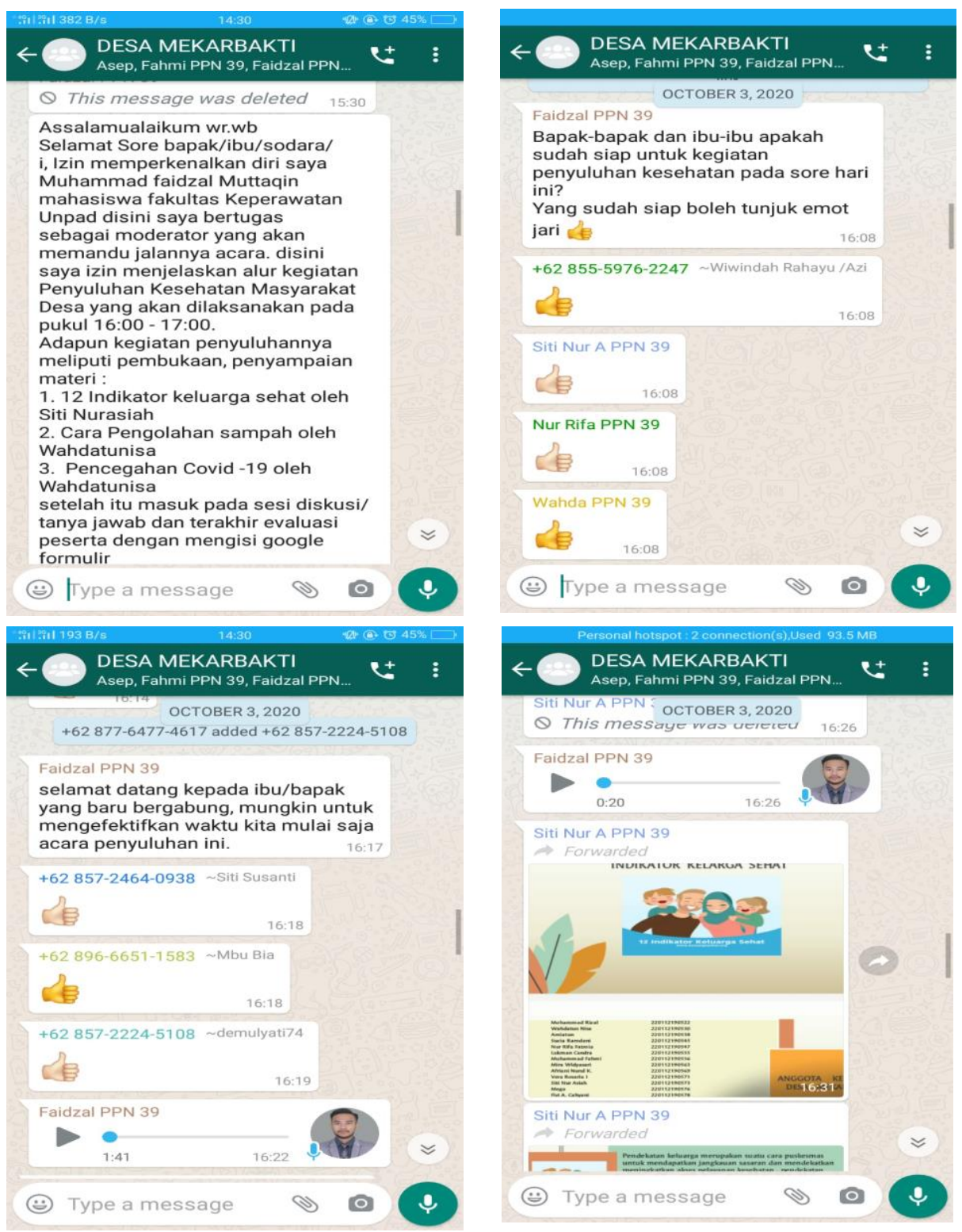

\section{SIMPULAN}

Kebutuhan belajar didapatkan bahwa kebutuhan belajar peserta warga masyarakat Desa Mekarbakti, meliputi kebutuhan belajar perceived needs, unperceived needs, dan misperceived needs. Pada proses pelaksanaan penyuluhan; peserta terlihat antusias saat pemberian materi berlangsung. Peserta mengikuti penyuluhan dengan senang hati karena penyuluhan dilaksanakan dengan menyenangkan. Kegiatan penyuluhan berjalan kondusif karena peserta memperhatikan materi yang disampaikan dengan baik

Wujud kegiatan pelaksanaan yang diberikan meliputi upaya promosi kesehatan Covid 19 yang dimulai dari definisi, faktor penyebab, faktor risiko, dan cara pencegahan penularan Covid 19 seperti mencuci tangan, menjaga jarak, menggunakan masker sesuai dengan protokol kesehatan pencegahan Covid 19 dari Kementerian Kesehatan Republik Indonesia. Selain itu, kegiatan promosi kesehatan lain yang dilakukan adalah pengendalian perilaku kesehatan berisiko seperti ketidakpatuhan masyarakat dalam 
mengikuti protokol kesehatan dan perilaku kesehatan sehari-hari seperti pengelolaan sampah yang belum efektif, dan masih banyaknya masyarakat yang merokok yang berpengaruh kepada indikator keluarga sehat.

Dimasa pandemi ini, kegiatan promosi kesehatan dilakukan dengan pemberian pendidikan kesehatan melalui virtual menggunakan platform Whatsapp Group Chat yang dihadiri oleh sejumlah stakeholder Desa Mekarbakti seperti petugas promosi kesehatan dari puskesmas haurngombong, bidan desa, kader dan masyarakat desa mekarbakti. Adapun media yang dipergunakan berupa poster yang telah didesain sedemikian rupa agar dapat menarik perhatian masyarakat

\section{DAFTAR PUSTAKA}

Alia, E. C. (2020). Perilaku Hidup Bersih Dan Sehat (Phbs) Dalam Pencegahan Covid-19. Jurnal Medika Malahayati, 4(4).

Depkes RI. 2014. Tentang Pelayanan Dasar Pusat Kesehatan Masyarakat. Jakarta: Depkes RI.

Ferry Efendi, M. (2009). Keperawatan Kesehatan Komunitas: teori dan praktik dalam keperawatan. Ferry Efendi.

Fitriani, N. I. (2020). Tinjauan Pustaka Covid-19: Virologi, Patogenesis, Dan Manifestasi Klinis. Jurnal Medika Malahayati, 4(3).

Husna, S., \& Ulliya, S. (2017). Gambaran Praktik five moment cuci tangan pada perawat di Rsud Soewondo Kendal.

Kushartanti, R. (2012). Beberapa faktor yang mempengaruhi perilaku cuci tangan pakai sabun (CTPS)(studi di Sekolah Dasar Negeri Brebes 3) (Doctoral dissertation, Program Pascasarjana Undip).

Lumongga, N., \& Syahrial, E. (2013). Pengaruh penyuluhan dengan metode ceramah dan diskusi terhadap peningkatan pengetahuan dan sikap anak tentang PHBS di Sekolah Dasar Negeri 065014 Kelurahan Namogajah Kecamatan Medan Tuntungan tahun 2013. Kebijakan, Promosi Kesehatan dan Biostatistika, 2(1), 14398.

Mubarak, W.I. 2017. Ilmu Keperawatan Komunitas. Jakarta: Salemba Medika. Suparti, S. (2017). 99++ Solusi Medis, Herbal \& Holistik Atasi Berbagai Penyakit. Jakarta: Penebar Plus+(PenebarGrup).

Susilo, A., Rumende, C. M., Pitoyo, C. W., Santoso, W. D., Yulianti, M., Herikurniawan, H., ... \& Yunihastuti, E. (2020). Coronavirus Disease 2019: Tinjauan Literatur Terkini. Jurnal Penyakit Dalam Indonesia, 7(1), 45-67.

Syapitri, H., Siregar, L. M., \& Saragih, F. L. (2020). Pencegahan Penularan Covid-19 Melalui Sosialisasi Dan Pembagian Masker Di Pasar Pringgan Medan. Jurnal Kreativitas Pengabdian Kepada Masyarakat (Pkm), 3(2), 422-29.

Widagdo, W., \& Kholifah, S. N. (2016). Keperawatan Keluarga dan Komunitas. PPSDM Kementerian Kesehatan Republik Indonesia.

Yuliana, Y. (2020). Corona virus diseases (Covid-19): Sebuah tinjauan literatur. Wellness And Healthy Magazine, 2(1), 187-192.

Zulva, T. N. I. (2020). Covid-19 Dan Kecenderungan Psikosomatis. J. Chem. Inf. Model, 1-4. 